\title{
Catholic-Dominant
}

\section{The Many Shapes of Interreligious Relations in Contemporary Spain}

\author{
Activism, Governance and Diplomacy
}

\author{
Mar Griera \\ Associate Professor, Facultat de Ciències Polítiques i Sociologia, Campus \\ UAB, Universitat Autònoma de Barcelona, Cerdanyola del Vallès, Barcelona, \\ Spain \\ mariadelmar.griera@uab.cat
}

\begin{abstract}
The idea of interreligious dialogue has gained worldwide traction in the last decades and has been promoted as a key component for religious peace. The aim of the article is to examine how interreligious aspirations and practices crystallize in different settings - namely diplomacy, governance and activism - and are shaped by the particular historical and political dynamics of each of these settings. The article explains how the plasticity of the idea of interreligious dialogue contributes to foster its popularity across different domains while serving to convey a wide range of meanings and expectations regarding interreligious pasts, presents and futures. Geographically, the article focuses on Spain and is based on qualitative fieldwork. The article shows that there have been considerable efforts to promote interreligious initiatives and that the global interreligious narrative has been re-fashioned locally, by including the idea of Al-Andalus as a lighthouse. However, the image of Spain and its history, as a foundational space for interreligious dialogue and multi-religious coexistence is contested by the current growth of extreme-right movements, and parties re-claiming the Christian foundational narrative of the country put this kind of initiative in peril.
\end{abstract}




\section{Keywords}

religious diversity - interreligious dialogue - Catholic Church - Spain - Islam Judaism - interfaith - governance - diplomacy

\section{Introduction}

The idea of interreligious dialogue has gained worldwide traction in recent decades and has been promoted as a key component for religious peace. However, there is not a clear and shared understanding of what it means and implies. The notion of interreligious dialogue has been used to refer to a broad range of practices and initiatives that exist across different geographical, social, cultural, religious and political contexts. ${ }^{1}$ There is not a scholarly consensus on the definition of interreligious dialogue but several disciplinary approaches that emphasize different aspects. ${ }^{2}$ In this article, I do not depart from a normative definition but I will delve into this complexity and explore empirically the multiple forms that the idea of interreligious dialogue takes in contemporary Spain.

The aim of the article is to examine how interreligious aspirations and practices crystallize in different settings - namely in diplomacy, governance and activism - and are shaped by the particular historical and political dynamics of each of these settings. Through several empirical illustrations I will show how the idea of interreligious dialogue unfolds in a very different manner depending on the actors that promote it, on the geographical space where it takes place and on the historical and current characteristics of the setting in which it develops. Therefore, I will demonstrate how the plasticity of the idea of interreligious dialogue contributes to foster its popularity across different domains while serving to convey a wide range of meanings and expectations regarding interreligious pasts, presents and futures.

Geographically, the article focuses on Spain, where the transformation of the religious landscape in the last decades has been rapid and remarkable. The Catholic hegemony that marked the country during the Franco dictatorship (1939-75) faded in the last decades of the 2oth century. The democratic system that emerged after the dictator's death granted religious freedom and rights to

1 Halafoff, The Multifaith Movement; Lamine, La Cohabitation des Dieux; Griera/Nagel, Interreligious Relations.

2 See also Lehman in the introduction of this issue of JRAT: Lehmann, Interreligious Dialogue in Context. 
religious minorities, and established freedom of conscience for everyone. This paved the way for the arrival of new religious minorities, the recognition of historical religious minorities and the (de)monopolization of the religious field. ${ }^{3}$ In parallel, the secularization process gained pace and the number of people declaring themselves as Catholic - or as practicing Catholics - diminished dramatically. ${ }^{4}$ Moreover, and especially from the two-thousands onwards, the growth of international migration flows contributed to the diversification of the country's religious landscape and gave new visibility to religious minorities.

The transformation of the Spanish religious has coincided with a rise in the vitality of religious identities globally. This new global context, in the case of Spain, came along with the impact of religious terrorism that hit both the city of Madrid (2004) and the city of Barcelona (2017). This, together with the rise of extreme-right populism and of islamophobia, has put interreligious coexistence on the political and media agenda. Amidst this context, there have been several attempts to re-visit the Spanish multi-religious past either to congratulate episodes of multi-religious peaceful coexistence or to commemorate violence against religious minorities. These processes of memory-making and memory-recovering have been key to forge a narrative relating democracy, religious pluralism and the relevance of interreligious dialogue.

Empirically, the article explores the different forms and paths that the idea of interreligious dialogue takes in three different domains - activism, governance and diplomacy. The parallel examination of each of these domains allows for a more comprehensive understanding of the dynamics of the interplay among religion, diversity and politics in contemporary Spain. This will also prevent me from offering a fictitiously homogeneous portrait of religious transformations in Spain. Sociologically, it is complicated to identify Spain as a homogeneous social, cultural and religious reality. The different territories of the country have significant differences - and also competing politicalterritorial aspirations - which make it inaccurate to describe the country's religious transformations in single terms. Therefore, to put the focuses on these three domains permits to better account for the specific dynamics at play in concrete settings, and to show the nuances and the complexities involved.

Methodologically, the article is based on a combination of research data gathered in the framework of different research projects in which I have been involved. On the one hand, the article draws on the interviews and observations collected in a research project on public policies and religious minorities,

3 Rozenberg, Minorías Religiosas y Construcción Democrática en España.

4 Pérez-Agote, Religion, Politics and Culture in Spain. 
especially focused on the case of Catalonia. ${ }^{5}$ On the other hand, I have used information - interviews with religious and political actors - collected during the development of the research project Urban Religious Expressions in Barcelona and Madrid. ${ }^{6}$ Finally, I am also including information (interviews and media analysis) gathered in the framework of a project - carried out collaboratively with two other colleagues (Marian Burchardt and Avi Astor) - on the controversies around the Cathedral-Mosque of Cordoba.

\section{2 \\ Context: Secularization, Religious Diversity and the Re-Positioning of the Catholic Church}

The history of Spain is a history of contrasts, especially in relation to religion. The country's religious past might be recounted in almost opposite ways. On the one hand, the religious history of the peninsula might be narrated by emphasizing its cosmopolitan and plural religious past, mainly as a result of its crucial location at the geographical intersection between Africa and Europe. The existence of Al-Andalus, and the well-known episodes of peaceful coexistence between Jewish, Christians and Muslims, serve to illustrate this account. ${ }^{7}$ However, at the same time, the history of Spain might also be narrated by highlighting the numerous and several violent historical episodes related to religion that have taken place throughout the centuries. The expulsion, or forced conversion, of Jews and Muslims in the 14th century, the outbreaks of physical violence against women and religious minorities orchestrated by the Catholic Inquisition or the role of the Catholic Church legitimating the Francoist dictatorship are some of the most famous ones. Not to forget the anticlerical violence at the beginning of the 2oth century, especially prevalent in Catalonia and Andalusia. ${ }^{8}$ Both narratives, the one emphasizing a history of coexistence and the other calling attention to the violent episodes of intolerance are embedded in the current understandings of the religious past. In addition, as I will more deeply explore later on in this article, both accounts are mobilized in contemporary interreligious initiatives and used to legitimate current interreligious encounters.

5 This fieldwork was part of my $\mathrm{PhD}$ dissertation defended in 2009, and of a follow-up developed during 2009-2011 and was funded by the Catalan Government.

6 The Project was funded by the Spanish Ministry of Economy and Competitivity (Ref. No. $\left.\mathrm{CSO}_{2015}-66198-\mathrm{P}\right)$.

7 Arigita, The 'Cordoba Paradigm'.

8 Delgado, La Ira Sagrada. 
Nowadays the country's religious landscape is far less polarized. There are four parallel trends that shape the country's religious map and that are important to take into account: a) the secularization process; b) the diversification of the religious field; c) the re-positioning of the Catholic Church and, d) the emergence of new spiritual movements. I will briefly describe the main characteristics of each of them.

Regarding the secularization process, as Pérez-Agote put forward, "Individual secularisation in Spain took place very late as a generalised process, in comparison to the countries in the North". ${ }^{9}$ The strength of the Catholic dictatorship somehow paused the secularization process that timidly already started in the early 2oth century. ${ }^{10}$ However, after the democratic transition, the secularization process gained speed and quickly assimilated Spain to what was happening in the rest of Southern Europe. The Catholic Church lost power and influence not only due to the new political context but also due to the rapid modernization and urbanization of Spain in a few decades. Statistical data show that the (de)monopolization of the country's religious field has been advancing in the last decades, and that there is still an important process of (de)churching going on. Currently, the number of people considering themselves as 'practicing Catholics' in Spain is rather low (20.5\%), despite the percentage of people who declare themselves as Catholic is higher $(67.2 \%) .{ }^{11}$ Catholicism has undergone a process of culturalization and the belonging to Catholicism is increasingly working as a cultural marker but not as an explanatory factor accounting for individual religious behaviour. This process of culturalization goes together with what, on another occasion, we termed as "Banal Catholicism",12 which refers to the persistence of traces of the former Catholic establishment in contemporary society - in the form of practices inherited from the old system (especially visible in public institutions such as hospitals, prisons and the police corps), the persistence of Catholic symbols in many public buildings and the participation of Catholic authorities in public events (mourning rituals, local celebrations). These are cultural forms that are usually taken for granted or considered banal but that serve to reproduce the cultural hegemony of the Catholic Church.

In relation to secularization, it is important to acknowledge that the process is far from geographically homogeneous. In territories like Catalonia or the

9 Pérez-Agote, Religion, Politics and Culture in Spain.

10 Estruch, Secularització i Pluralisme en la Societat Catalana d'avui.

11 Barómetro del CIS. January 2020.

12 Griera/Clot-Garrell, Banal is not Trivial. 
Basque Country the percentages of secularization are considerably higher. ${ }^{13}$ The differences are also generational. Younger generations, especially in urban and northern areas, are highly secularized. ${ }^{14}$

The second important process that is changing the religious landscape is the growth of religious minorities, mainly - but not only - related with the rise of international migration coming from Africa, Latin America and Asia. According to the Observatorio del Pluralismo Religioso, there are 7234 worship centers $^{15}$ in Spain that belong to religious minorities. An important number of these worship centers have been created in the last two decades, and this number is still growing fast. The religious community with a major number of worship centers (besides Catholicism) are Evangelical churches, with 4238 churches distributed across Spain. A majority of them are Pentecostal or charismatic, which are especially popular among the Roma population ${ }^{16}$ and migrants coming from Latin America. There are 1632 Muslim worship places, many of them are in Catalonia and Andalusia. The Muslim population in Spain is mainly of Moroccan origin, however, there is also an important convert community that has played a key role in representing Islam in the public space, and also in fostering interreligious initiatives. In the last years, there has also been a growth of Muslim communities with other geographical backgrounds such as Bangladeshi communities in Madrid ${ }^{17}$ or Pakistani communities in Barcelona. ${ }^{18}$ The third minority, in number of worship centers, are Jehovah's Witnesses (627 centers). Jehovah's Witnesses rapidly increased the number of Kingdom Halls during the eighties and nineties but not nowadays. Currently, groups such as the Orthodox Church (216 worship places) or the Buddhist community (171 centers) grow in a more rapid way..$^{19}$ This religious diversification is, again, far more visible within the younger generation and in specific territories. The diversification of the country is deeper in Barcelona, Andalusia

13 For instance, in Catalonia, the number of those identifying themselves as Catholic is no more than $50 \%$ (the average for Spain is almost $70 \%$ ), while those who consider themselves as practising Catholics are less than $12 \%$ of the population.

14 For instance, in Catalonia, only 34\% of those between the ages 16 and 24 years declare themselves as Catholic, and $74 \%$ declare that they have not participated in a religious service in the last year (so, there is at least $10 \%$ of those declaring Catholic who have no religious practice at all). National minorities' communities have some particular characteristics regarding religion but in the other territories, younger generations are also more secularized.

15 See www.observatorioreligion.es.

16 Montañes, Etnicidad e Identidad; Cantón Delgado, Gitanos Pentecostales.

17 Salguero Montaño, Estrategias de Institucionalización del Islam en Contextos Migratorios.

18 Moreras, ¿Ravalistán? Islam y Configuración Comunitaria.

19 See Díez de Velasco, Budismo en España. 
and Madrid than in other areas. This helps to explain, in part, why interreligious initiatives are not homogeneously distributed throughout the country, and why religious issues have been more salient in the political agenda in some territories than others.

The third process that is worth acknowledging is the re-positioning of the Catholic Church in the new scenario of secularization and diversification. The role of the Catholic Church is far from monolithic but it is possible to distinguish between different trends. On the one hand, from 2004 onwards, there has been a process of re-politization of the Catholic Church and of an increased involvement of Catholic actors in the public sphere, which have translated into an increasing participation of church authorities in public moral debates (e.g. abortion or religious education), in the organization of public events (e.g. Pope's visit or the Day of the Family) ${ }^{20}$ or in claiming the relevance of Christianity in definitions of national identity. Conservative Catholic movements such as the Neocatechumenals or the Opus Dei have been the main actors behind the scenes despite there being a complex constellation of actors, movements and organizations that give support to this increasing public role of the Catholic Church. In recent years, this type of movement has also fuelled the rise of extreme right parties despite the support they get being far from homogenous among conservative Christian groups. On the other hand, the Catholic Church keeps a strong social power due to its enormous network of social assistance organizations, which run ${ }^{21}$ as a parallel system to the welfare system and become key in dealing with social issues. The existence of countless organizations, a high number of volunteers that offer their time and money to church social programs and the existence of a vast network of Catholic schools, has converted the Catholic Church into a powerful social movement. While within this social milieu there is coexistence among different ideological stances, there is an important core of very active left-wing Christians who have historically played an important political role. Likewise, it is important to acknowledge the existence of an important number of Catholic actors - some of them connected to monastic orders, theology faculties and Catholic entities - that work to re-think and re-adapt the role of Catholicism in contemporary Spain. Some of these factions have their origin in the Catholic activist milieus that were very relevant in the late seventies but some others have a more recent origin. Many of them still have an activist approach while others are increasingly interested in exploring Catholic spirituality through new avenues such as Christian meditation, monastic interreligious dialogue or

20 Cornejo Valle/Pichardo Galán, Actores y Estrategias.

21 Itçaina, The Roman Catholic Church and the Immigration Issue. 
ecumenical encounters. Their aim is to renovate Catholicism without forgiving the spiritual roots, and by promoting an open understanding of the faith (and of its relationship with other religious groups). There are some of these actors that, in some moments, have an important visibility in the public sphere. ${ }^{22}$

Finally, it is also important to mention the increasing relevance of holistic spirituality, and the growing number of the population participating in the holistic milieu. ${ }^{23}$ The popularization of eastern spiritual practices, the increase of holistic self-help literature or the rise in the number of people who declare to be spiritual but not religious are indications of a process of transformation of religious life. Traditional institutions lose prominence as providers of life meaning and as facilitators of transcendence experience. The search for spiritual fullness ${ }^{24}$ takes new routes and goes beyond classical categories in the religious field. This makes it possible to understand the existence of a growing number of participants in interreligious encounters that do not hold a traditional religious affiliation but define themselves as spiritual, and engage in interreligious activities searching to cultivate values as transcendence, hospitality and communion.

All in all, the religious landscape has considerably changed in recent years, which has opened new routes for interreligious dialogue and has also generated a more complex scenario.

A glance over the religious landscape shows that there is a growing number of practices, encounters or initiatives that are referred to as promoting interreligious dialogue while exhibiting considerable differences among them. As I already mentioned, in this article I put the attention on three different settings, which I consider to be privileged sites for analyzing the evolution of interreligious dialogue initiatives in Spain. Specifically, I focus on practices of interreligious dialogue emerging within: a) social and religious activism; b) governance, and c) diplomacy and foreign affairs relations. These three sectors are neither exclusive nor exhaustive but to analyze them allows us to get a general picture of the current development of interreligious dialogue.

22 This category involves very different types of religious actors, to name just a few of them: Pablo d'Ors, Juan José Tamayo, Francesc Torradeflot, Federico Mayor Zaragosa or Teresa Forcades.

23 Heelas/Woodhead/Seel/Szerszynski/Tusting, The Spiritual Revolution.

24 Taylor, A Secular Age. 


\subsection{From Ecumenism to Interreligious Activism}

The origin of contemporary interreligious dialogue in Spain lies in the first ecumenical groups that were formed underground in the 1950s. In those days, Spain was still in the midst of the dictatorship and the most conservative sectors of the Catholic Church had great power, which made it difficult to promote ecumenical activities openly. One of the first contacts between Spanish Catholics and Evangelicals began in Barcelona in 1954 on the occasion of a visit from a pastor of the Swedish Church who was very close to one of the world pioneers of ecumenism Father Couturier, Dr. Gunner Rosendal. The first ecumenical association was created then in Barcelona, with the support of the Christian organization Pax Christi, and the involvement of several protestant pastors and Catholic monks. ${ }^{25}$ Similar contacts also started in Madrid a bit later. It was at this time when the Week of Prayer for Christian Unity began to be celebrated in some parishes and seminars. The ecumenical activity started to spread underground, but gained tentative official recognition in 1959 when in the framework of the celebration of the Week of Christian Unity the Archbishop of Tarragona, Josep Pont i Gol, granted the "imprimatur" (permission) for the Spanish edition of fifteen thousand copies of the universal prayer for the unity of Christians of Father Couturier. These copies were then distributed throughout Spain.

Some years after, the celebration of the Second Vatican Council and the promulgation of the Encyclical Dignitatis Humanae played an important role in bringing to light a new conception of religious freedom and of ecumenical dialogue. ${ }^{26}$ Likewise, from that moment on, ecumenical initiatives multiplied in Spain. ${ }^{27}$ In Salamanca, the Ecumenical Center "Juan XxIII" was founded in 1967 by D. José Sanchez Vaquero who was also the Chair of Oriental Theology at the Pontifical University. Also in Valencia, a bit later, a Catholic monk and professor of theology (Joan Bosch), together with the collaboration of an Anglican pastor, promoted the creation of the Interconfessional Center which is still active nowadays. Likewise, a group of people created the centre "Missionaries of Unity" in Segovia to promote the ecumenical cause. It was also around this time that the monks of Taizé began to visit Spain to offer conferences and to spread ecumenical ideas. Contacts between Christians increased and extended on the occasion of the Unity Week, and through the many other encounters

25 The role of the the Capuchin Joan Botam, and of some monks for the Monastery of Montserrat, was especially remarkable. Casañas, El Progressisme Catòlic a Catalunya (1940-1980), p. 143.

26 Casañas, El Progressisme Catòlic a Catalunya (1940-1980).

27 García Hernando, Colaboración Ecuménica en España. 
that were organized. During these years, most of the efforts of these groups were focused on generating bridges among communities, especially among their leaders. Moreover, the role of intellectuals (e.g. José Luis Aranguren, ${ }^{28}$ Joan Estruch ${ }^{29}$ or Juan José Tamayo) was crucial to foster the visibility of the ecumenical movement and to establish bridges between the religious and the academic milieu. However, ecumenical groups were also very active in the denunciation of the dictatorship and in the dissemination of a new way of conceiving interreligious coexistence, and they often organized activities to pressure civil and ecclesiastical authorities to promote religious freedom. ${ }^{30}$

In parallel to the rise of intra-Christian dialogue, there were also initiatives aimed at fostering the relationship between Christians and Jews. In this regard, the association Amistad Judeo-Cristiana was founded in 1961 on the initiative of the religious of the Congregation of Our Lady of Sion and a group of Catholic priests who defended the rapprochement between Christianity and Judaism. The association, which was initially present in Madrid and Barcelona - and afterwards also in Valencia -, aimed at fighting prejudices and creating bridges of friendship between Christians and Jews in Spain. ${ }^{31}$

These movements were quite revolutionary for the times in which the Catholic Church was still giving formal support to the Dictatorship and the idea of the Spanish nation was inextricably bounded to Catholicism. During the seventies and the eighties these groups gained more explicit recognition from the Catholic Church while they were continuing their activities without experiencing a dramatic growth in members and activities. The movement was always more numerous and dynamic in Barcelona than in Madrid. ${ }^{32}$ In this vein, Luis Ruiz Poveda, Evangelical pastor and pioneer of ecumenism, stated "ecumenical work was much more complicated and difficult [in Madrid] than in Barcelona, for the hermetically closed positions of Madrid's Protestants and Catholics". 33

In the late eighties and nineties, the ecumenical movement gradually underwent a transformation and many organizations and encounters mutated to become interreligious. In Barcelona, and especially due to the impact of the

\footnotetext{
28 Aranguren, Catolicismo y Protestantismo como Formas de Existencia.

29 Estruch, Los Protestantes Españoles.

30 For example, the Ecumenical Center wrote a letter to the drafting committee of the Religious Freedom Act calling for the Council's "Declaration on Religious Freedom" to be applied everywhere.

31 See Bramon, ¿También Civilización Islamo-Cristiana?.

32 On the comparison of Madrid and Barcelona on religious affairs, see also Astor/Griera/ Cornejo, Religious Governance.

33 Poveda, El Ecumenismo y los Ecumenismos en España, p. 38o.
} 
celebration of the Olympic Games in 1992, interreligious contacts increased and the first interreligious commission was established in the early nineties. ${ }^{34}$ This fostered the collaboration and the dialogue among representatives of the main city's religious communities (Catholics, Protestants, Orthodox Christians, Jews, Buddhists, Brama Kumaris and Bahá'ís), and was the antecedent for the creation of the first proper interreligious association, which was the UNESCO Association for Interreligious Dialogue founded in Barcelona in 1999. This association was conceived as a grassroots organization, bringing together members of different religious communities (not only official leaders nor only members of main world religions). This Association was also behind the organization of the Parliament of World's Religions in 2004, ${ }^{35}$ and has been the promoter of many other grassroots interreligious organizations that have been founded in Catalonia, Valencia and the Balearic Islands in the last two decades as well. Currently, there are 19 associations grouped within the framework of the Catalan Network of Interreligious Dialogue, ${ }^{36}$ which is a very active network that has been organizing the Catalan Interfaith Parliament every two years ${ }^{37}$ and has also been working as a lobby to promote good religious coexistence and public recognition of religious diversity. The network, and the entities belonging to them, have also developed an important task of promoting groups or circles of interreligious dialogue organized by interests (e.g. interreligious dialogue and ecology), by age (youth group), by gender (woman/ man groups) or by profession (academics, monk) among others. In the last decades, similar groups have also been created in many other territories across Spain (e.g. the Basque Country, Andalusia or the Canary Islands).

Many of these associations were created around 2004, after the celebration of the Parliament of the World's Religions in Barcelona and also the terrorist attacks in Madrid. The attacks contributed to raise awareness about the necessity to promote good coexistence among religious groups in order to prevent future attacks but also about the relevance to lay down measures to avoid Islamophobic reactions. This scenario fostered the creation of new

34 The Olympic Committee ask the City Council of Barcelona to accommodate the religious needs of athletes and their families and the City Council commissioned this task to the Ecumenical Center and the newly created Interreligious Community. See Griera, Public Policies, Interfaith Associations and Religious Minorities.

35 The Parliament took place during the 7-10 July 2004 and gathered more than 9.ooo persons and more than 600 activities were organized.

36 See Audir.org: Xarxa Catalana d'Entitats.

37 Now it switched to be every four years because it has been considered that it is preferable to keep the energy to organize a big event only every four years, and put the focus on smaller activities reaching new people. 
interreligious groups and encouraged the organization of interreligious encounters throughout the country. The rise of interreligious dialogue was very fast in 2004-05, becoming more gradual during the following years. We do not count with updated empirical data on the number of interreligious groups existing in Spain but, according to the calculations of Francesc Torradeflot - one of the most important promoters of interreligious dialogue in the country there are around 50 interreligious groups. ${ }^{38}$

Nowadays the interreligious movement is highly diverse but has common features. First, most of the interreligious groups do not place the main emphasis on the theological dialogue but on the idea of dialogue as space of encounter, as a site for creating opportunities for bridging and bonding among members of different religions. Therefore, while many of the initial ecumenical activities were aimed at developing theological reasonings, and in finding religious-moral arguments to justify the importance of building bridges among faiths, most of the new groups devote very little effort - if none at all - to discuss theological positions. Second, there is a significant specialization in the interreligious field and a high heterogeneity of entities. That is to say, we can distinguish between entities depending on their composition (grassroots or leaders), the number of religious organizations that are included (bilateral dialogue, multilateral - only Abrahamic faiths, only World Religions or open to everyone), their main aim (academic, theological, social, representational) and their reach (local, regional, national). This makes a very diverse interreligious field and shows the malleability of the idea of interreligious dialogue. The third characteristic is the important role of the Catholic Church in this scenario. During the last decades, the Catholic Church has increased its formal support to interreligious activities. Most Spanish bishops have appointed a delegate for interreligious dialogue and regularly participate in interreligious meetings, ${ }^{39}$ and some religious orders (Capuchins, Benedictines, Jesuits, among others) have had an essential role in the promotion of interreligious dialogue groups. However, it is also important to acknowledge the role of other individuals, especially some of them coming from minority religious communities (especially protestant, Buddhist, Baha'i and Jewish) who have had a crucial role in this scenario.

38 See Torradeflot, Las Vías del Diálogo Interreligioso en España, www.observatorioreligion.es.

39 See www.diocesismalaga.es/ecumenismo/, Ecumenismo y Diálogo interreligioso. 


\subsection{From Interreligious Dialogue to the Governance of Religious Diversity}

In the last two decades, religious affairs have gained political significance worldwide. The new global relevance of religion and its impact on Spanish soil have put into question the secularization narrative, which was prevalent since the transition to democracy in the late seventies until the beginning of the two thousands. ${ }^{40}$ Religious diversity issues have entered the political and media agenda giving visibility ${ }^{41}$ to this topic and new forms of governance of religious diversity have emerged. As Tuomas Martikainen put forward, all over Europe multilevel and pluricentric governance networks have become "a new and increasingly important modality in the state's efforts to regulate religion [...]" that aim to

coordinate religion for many different ends, including good ethnic relations, social cohesion, better (or less costly) provision of welfare and so on. Whereas the actual (national) contexts of these shifts in emphasis matter and respond in their own ways, still the general direction of movement is towards a closer relationship between many (if not all) religious organizations and the state. ${ }^{42}$

In the case of Spain, the year 2004 marked a critical juncture regarding the political governance of religious diversity. Until then, the state-church regime born out during the transition to democracy completely the governance of the religious field and public policies aiming to accommodate religious diversity issues were almost non-existent. In this way, despite the government signed cooperation agreements with religious minority groups (Protestants, Muslims and Jews) in 1992 these were mainly formal, with a strong diplomatic dimension, and with no policy measures (no budget) aimed to implement them. ${ }^{43}$ However, as I already mentioned, the terrorist attacks (Madrid, March 2004) generated the perception of the necessity to reformulate the government approach to religious affairs. As Mercedes Rico, the director of the Office of Religious Affairs of the Spanish government (2004-08), stated “[...] the bombing attacks were a 'turning point' for all of us and when I took over the position

40 Pérez-Agote, Religion, Politics and Culture in Spain.

41 Díez de Velasco, The Visibilization of Religious Minorities in Spain.

42 Martikainen, Multilevel and Pluricentric Network Governance of Religion, p. 141.

43 Motilla, El Islam en España: Marco Legal. 
of Director of Religious Affairs I was convinced of the need to foster a new approach towards religious minority issues". ${ }^{44}$

The attacks opened a policy window since religious diversity policies were considered, along with security policies, crucial to fighting Islamic fundamentalism and also right-wing extremism. In addition, the attacks coincided with an important rise of religious diversity due to the fast influx of immigrants coming from the Global South. ${ }^{45}$ Religious minority groups - not only Muslims but also Evangelicals, Sikhs or Christian Orthodox among others - were growing exponentially, and were raising new accommodation claims and demands. This contributed to give weight to religious affairs policies. The first and most important policy initiative that the Spanish government took in this regard was the creation of a public foundation, called Fundación Pluralismo y Convivencia (Pluralism and Coexistence Foundation). The Foundation describes its mandate in the following terms: "Our mission is to encourage the recognition and accommodation of religious diversity as basic elements for guaranteeing the effective exercise of religious freedom and the construction of an adequate framework for coexistence." ${ }^{46}$ The Foundation has not only strongly encouraged interreligious dialogue initiatives but has also become a space of dialogue in its own right since various religious representatives (Muslims, Jews, Buddhists, Mormons and Protestants) participate in its governance structure. Although the Foundation is funded through public money, religious minority representatives belong to its board of trustees and have a say in the decisionmaking process. During its fifteen years of existence, the Foundation has had a key role in fostering interreligious dialogue initiatives directly and indirectly. On the one hand, the Foundation has encouraged dialogue among religious leaders and has organized several interreligious encounters at different levels. Some of these initiatives are related with diplomatic or foreign affairs policies (which I will more directly refer to in the following section), many others have been aimed at "smoothening" the governance of religious diversity in Spain and some others have more directly targeted specific groups (e.g. the Foundation has, in collaboration with other entities, promoted interreligious dialogue among youth). On the other hand, the Foundation has played a strategical role in promoting interreligious dialogue initiatives through indirect means such are the provision of funding to interreligious entities, the dissemination of good interreligious dialogue practices among religious and public actors and the public encouragement of a culture of interreligious dialogue. In this regard, as Avi Astor states:

45 Martínez-Ariño et al., Immigración, Diversidad Religiosa y Centros de Culto.

46 See Fundación pluralismo y convivencia, La Fundación. 
[...] in addition to providing public funding to religious minorities, the Foundation developed aseries of initiatives aimed at promoting public awareness and toleration of religious diversity, improving data on the presence of religious minorities, and facilitating access to resources of use to actors involved in religious governance. ${ }^{47}$

However, not only the Foundation has promoted interreligious dialogue but many local governments, too. On the one hand, the Foundation created the Observatorio del Pluralismo Religioso (Observatory of Religious Pluralism) in 2011 aimed at encouraging local governments to develop a more proactive policy towards religious diversity affairs, and to develop a policy in concordance with the Foundation principles. The website of the Observatory became a repository for the dissemination of good practices in matters of accommodation of religious diversity and promotion of inter-religious dialogue. In addition, the Observatory has organized training courses for local authorities and workshops on the subject in many municipalities. Likewise, the Observatory published and disseminated a guide aimed at giving tools to local actors in order to put interreligious initiatives into practice. ${ }^{48}$ These initiatives have contributed to foster a soft governance regime of religious diversity based in smoothing the relationship among religious communities but also between religious communities and local governments. Not everyone perceives these policies as well-intentioned attempts to foster inclusivity, equality and recognition in the religious field but some "contend that such initiatives are not driven by the objective of promoting religious freedom and social integration, but rather by the objective of controlling and domesticating Islam". 49

A glance over the current situation shows that the adoption of the idea of interreligious dialogue as a policy tool by local governments has taken different patterns. First, some municipalities have directly fostered the creation of 'interreligious councils', attached to local governments, composed by local religious leaders or experts. This type of interreligious council acts as a forum for advising public authorities in matters of religious diversity, as well as spaces for deliberation on policies to promote in this area. Second, some municipalities have not promoted interfaith councils directly, but took advantage of the existence of an interreligious group in the town to promote joint policy action and to establish stable channels of dialogue and contact. The city council provides funding for these groups, and also visibility and a public voice. Third, there are

\footnotetext{
47 Astor, Governing Religious Diversity, p. 257.

48 The guide was written by the interreligious leader and pioneer Francesc Torradeflot. See Torradeflot, Las Vías del Diálogo Interreligioso en España. 
some town councils that establish specific collaborations with the local interreligious dialogue group(s) with a very concrete objective. This is the case, for example, of the town councils that ask local interreligious groups to organize an open day of worship centers, or that ask for collaboration from interfaith groups to manage a local crisis or to organize a mourning ceremony for an event that has occurred. As I developed elsewhere, ${ }^{50}$ local councils and interreligious groups can find different avenues for collaboration. The most important are a) the politics of representation, which refers to the role of interreligious groups in representing religious diversity in public and political events; b) the politics of dissemination, interreligious groups act pedagogically to promote a narrative emphasizing the importance of interreligious dialogue and good coexistence among different religious communities. This might be done by promoting religious minorities' open days centers, festivals of religions, organizing activities for schools and so on) the politics of mediation, which refers to when interreligious dialogue groups or leaders work in collaboration with the city council to smooth local tensions or specific conflicts. Throughout Spain, conflicts for the opening of worship centers have been quite frequent - especially related with the opening of mosques but also Evangelical churches or Sikh gurdwaras. In this regard, Burchianti and Itçaina stated:

[...] it is the conflict about the building of mosques that is most frequent in the local public arena, calling into question action by local authorities, in particular by municipalities. [...] With the proliferation of these conflicts and under the Madrid bombings, local authorities are attempting to introduce preventive policies, combining interreligious and intercultural dialogue in order to defuse possible conflicts threatening the coexistence that is the political credo of municipalities with a substantial foreign presence. ${ }^{51}$

Before concluding this section, it is important to remark that not only local governments have had a key role in promoting interreligious dialogue activities but also regional governments. In this case, it is mandatory to mention the case of the Catalan Government, which already developed a policy program on religious diversity affairs much earlier than the Spanish government. ${ }^{52}$ The case of Catalonia is particular because aspirations of self-government,

50 Griera/Forteza, New Actors on the Governance of Religious Diversity.

51 Burchianti/Itçaina, Local Authorities and Interfaith Dialogue in Spain, p. 124.

$5^{2}$ Seglers, Autogovern i fet Religiós; Griera, The Governance of Religious Diversity in Stateless Nations; Burchardt, Recalling Modernity. 
together with a much more friendly and inclusive approach to minorities than the Spanish central government, has generated a highly proactive policy on religious diversity issues in which interreligious groups have played a key role. The Basque Country also shows some particularities but not as marked as in Catalonia due to several factors (religious minorities are much less numerous, and the Basque nationalist view over ethnicity and religion is very different from the Catalan). However, to deeply explore the Catalan or Basque cases would deserve an article of its own.

\subsection{Interreligious Dialogue as a Diplomatic Tool}

The year 1992 was important in symbolic terms for Spain as it marked the 5ooth anniversary of the expulsion of Jews and Muslims from the peninsula. Coinciding with the commemoration, the Spanish government accelerated the approval of three bills aimed at promoting the recognition of Jewish, Muslim and Protestant minorities. The Ministry of Justice framed the approval of these three Cooperation Agreements in the Spanish Congress in the following terms:

The agreements come to fill that gap, which has been a gap since the Constitution, but which is undoubtedly also a gap that we had pending for 500 years [...]. We comply, therefore, with articles 16 and 9 of the Spanish Constitution, we also comply with the spirit of the Constitution and heal some of the old wounds present in our country. ${ }^{53}$

The signing of the Agreements was widely celebrated and unanimously marked as a historic milestone. The coincidence - not accidental - of the signing of the agreements with the commemorations of the fifth centenary contributed to give more pomp and historical significance to the events. Numerous celebratory acts performed. Thus, for example, on March 31, 1992 in the synagogue of Madrid

[...] King Juan Carlos, accompanied by various members of the Government, and in the presence of the President of the State of Israel, Haïm Herzog, sealed "the symbolic reunion of the Crown with the Sephardim", affirming in the same speech the full right of the JudeoSpanish to obtain the nationality. Attendees perceived this ceremony as the historical reconciliation between the Jewish people and the people of Spain. ${ }^{54}$

53 Tomas de la Quadra Salcedo, Psoe, Spanish Congress.

54 Rozenberg, Minorías Religiosas y Construcción Democrática en España, p. 256. 
It was not the only celebration. An exhibition on the Al-Andalus was organized at the Alhambra in Granada, and numerous conferences, exhibitions and interreligious dialogue activities were also held all over the country. The Agreements became a kind of historical compensation for the Jewish and Muslim communities while generating a new framework for regulating religious minorities, which in theoretical terms offered a new and more accommodative framework for religious minorities. However, although the Agreements were considered to be one of the most advanced in Europe at the time, ${ }^{55}$ much of their content has never been effective. As I already mentioned above, the agreements were not accompanied by a corresponding public budget or any implementing regulations. ${ }^{56}$

The agreements were, mainly, conceived as an act of historical reconciliation, as well as being used to gain geographical influence and international prestige - especially in relation to Israel but also to the Arab World. In this regard, a few months later, in the Palace of Medina Al-Sahara (Córdoba), a celebratory event took place with the participation of the General President of the League of Arab States, Mr. Esmat Abdel Meguid and the Spanish King Juan Carlos I among many other Spanish politicians and academics and diplomats from the Arab world. At the event, the King Juan Carlos ended his discourse with the following words:

Al-Andalus should be the model to build a new framework of relationship in the Mediterranean area. Security, cooperation and human dimension are essential elements of this new coexistence among all the countries of the area. Only by eradicating the evils of insecurity, strengthening economic and financial cooperation and promoting cultural dialogue and tolerance of beliefs and behaviors, can we build a new space of peace and stability. ${ }^{57}$

Likewise, the commemoration of the $5^{\text {th }}$ centenary of the expulsion of Jews and Muslims from the peninsula acted as a catalyst for spreading the idea of Al-Andalus as the paradigm of interfaith coexistence. A paradigm that, since

55 Motilla, El Islam en España: Marco Legal.

$5^{6}$ In addition, many of the issues that were regulated (burial ceremonies, cemeteries, education, etc.) were the responsibility of the autonomies or local governments but they were not informed about the existence of the agreements and about their implications (not transferred budget to implement it).

57 See Casa De Su Majestad El Rey. Actividades e Agenda. Palabras de Su Majestad el Rey en el acto institucional Al-Andalus. 
then, has gained influence and popularity not only in Spain but throughout the world. The invocation to the memory of Al-Andalus has been used as a symbolic antidote against the thesis of the clash of civilizations. Barack Obama's use of the idea of the Cordoba paradigm ${ }^{58}$ is famous, but so is the theorizing of the subject by the Iranian intellectual Ramin Jahanbegloo. Al-Andalus is built as an ideal past that not only has to be rescued from memory but that can serve as a means to imagine the future. The invocation of this past, and the moral duty to make it a reference for the future, appear as key elements to justify the central role that Spain aims to play in interreligious diplomacy.

Taking advantage of the historical heritage of Al-Andalus and the strategic position of Spain in the Mediterranean, the Spanish government has wanted to bet on cultural and/or interreligious dialogue as a diplomatic tool. There are different episodes that are relevant in this regard. The Barcelona process in 1995 was a first impulse, although at this time the reference was the 'cultural dialogue' but no interreligious one. Likewise, as De Perini puts forward:

The turning point for the consolidation of Inter-Cultural Dialogue (ICD) was achieved in the context of the EMP Valencia Conference, held under the Spanish Presidency of the EU in April 2002. On this occasion, the spirit of initiative of the Prodi Commission met with the voluntarism of Spain and Sweden, which had been pioneers in the promotion of ICD in the Mediterranean. ${ }^{59}$

Later, and also as a consequence of the 2004 terrorist attacks, Rodríguez Zapatero - the Spanish president of that time - made many efforts to promote the Alliance of Civilizations as an idea and a tool to counter-act the clash of civilization thesis, and to foster interreligious dialogue at the international level. Likewise, the involvement of the Spanish government in organizations such as KAIICID or in the promotion of the Anna Lindh Foundation have also been aimed to promote interreligious dialogue as a diplomatic tool.

Al-Andalus has not only been an intellectual reference. Also at a concrete, spatial level, it has become a privileged place for the organization of international forums for Muslim Christian dialogue (especially in the seventies) or interreligious dialogue in recent times. These are, for example, the organization of a high-level meeting of the European Union (03.05.2010) aimed at developing article 17.3 of the Lisbon Treaty or the recent creation of the Cordoba

$5^{8}$ Arigita, The 'Cordoba Paradigm'

59 De Perini, The Changing Scope of Intercultural Dialogue in EU, p. 14. 
Forum (2018) with the involvement of organizations such as KAIICID, the Fondation Ousseimi, AISA ONG International, the Nicolas Puech Foundation, Initiatives for International Change or Salam among others. The existence of a rich multi-religious heritage - not only in Andalusia but also in Toledo, Palma de Mallorca and many other places - has helped to give shape, to materialize, ideas of interreligious tolerance, and to offer material scenarios to illustrate interreligious ideas. ${ }^{60}$

\section{$4 \quad$ Concluding Remarks}

The exploration of the emergence and evolution of the idea of interreligious dialogue in three different domains has allowed the illustration of the plasticity of this notion and its parallel development. The three domains hold connections among them, which become more evident in particular historical moments (e.g. in 1992 or after the 2004 terrorist attacks) or in specific material scenarios (e.g. Cordoba). The advancement of interreligious dialogue practices has generated cross-fertilizations of insights and experiences across domains and has also contributed to give more legitimacy to the notion in general. In this way, the development of a wide activist network of interreligious activists was crucial for the implementation of the idea of interreligious dialogue as a governance tool. Likewise, the existence of 'successful' local practices of interreligious dialogue is often used to legitimize the relevance of interreligious dialogue at the international level. However, it is important to state that the idea of interreligious dialogue also assumes its particular meaning and shape within each of the domains, and works relatively autonomously. Therefore, international efforts to promote the Alliance of Civilization have had little impact into the interreligious activist field, as well as many governance initiatives aimed at promoting dialogue institutionally have almost no repercussions on the local communities.

The specificity of each of the three domains makes it difficult to delineate the main characteristics that interreligious dialogue takes in contemporary times in general. However, I will emphasize three aspects. On the one hand, dialogue initiatives have in common that they are aimed to build bridges. These initiatives aim to put together persons/entities with (non-)religious affiliations and create bridges (with all the ambiguity that this word might

6o Griera/Burchardt/Astor, European Identities, Heritage, and the Iconic Power of MultiReligious Buildings. 
carry) between them. There are initiatives that aim to build bridges taking a top down perspective (diplomatic ones) and others that take a bottom up approach (activist ones), while others aim also create bridges between the religious and the secular fields (governance). On the other hand, these dialogue initiatives are legitimated by a narrative that emphasizes the relevance of cultural/religious tools to foster a peaceful and better world. A narrative that has been reinforced by working as a counter narrative to the one of the clash of civilizations, and has been spread by multiple actors - despite running the risk of reificating religious identities and hiding the material side of world conflicts and inequalities. Third, there have been considerable efforts to promote interreligious initiatives in Spain in the last decades, and the global interreligious narrative has been re-fashioned locally, by including the idea of Al-Andalus as a lighthouse.

However, before concluding, it is important to state that not all of these interreligious efforts have been successful. Likewise, the image of Spain, and its history, as a foundational space for interreligious dialogue and multi-religious coexistence, has been contested repeatedly. If it is true that Jewish, Muslim and Christian communities lived together for a certain time in medieval history, it is equally true that this historical period ended with the expulsion of these communities, and the forced conversion of many of their members. Likewise, it is important to remember that this is still called the 'Reconquista' in many contexts, especially by the new and growing right-wing movements and political parties. At the same time, while the Spanish government has aimed to play a key role as an international leader of interreligious dialogue, and has formally supported interreligious initiatives, this has not always been translated into an effective internal policy of accommodation of religious minorities.

\section{Acknowledgement}

I would like to thank Avi Astor, Monica Cornejo, Francisco Díez de Velasco, Rosa Martínez-Cuadros, Julia Martínez-Ariño and Marian Burchardt for their insights into this topic, and for the conversations that have helped me to figure out a general picture on the interreligious dynamics in contemporary Spain. I am also deeply grateful to Karsten Lehmann for his invitation to participate in the symposium (The conference 'Interreligious Dialogue in Context: A European Comparison (IRD-Con)' took place between October 17th and 19th 2019 in Vienna, Austria) and in this issue of JRAT (Lehmann, Interreligious Dialogue in Context), and to all the participants for their ideas and comments. 


\section{Biography}

Dr Mar Griera is currently the director of the research group ISOR (research centre for the study of religion) and an Associate Professor in the Sociology Department at the Universitat Autònoma de Barcelona (UAB). She is also Vice-Dean in the Faculty of Political Science and Sociology of the UAB. Her main research expertise lies at the intersection of religion, spirituality, identity and heritage regimes in contemporary Europe.

\section{Bibliography}

Arigita, Elena: The 'Cordoba Paradigm': Memory and Silence around Europe's Islamic Past, in: Frank Peter/Sarah Dornhof/Elena Arigita (eds.): Islam and the Politics of Culture in Europe: Memory, Aesthetics, Art. Bielefeld: Transcript, 2013, pp. 21-40.

Aranguren, José Luis: Catolicismo y Protestantismo como Formas de Existencia, in: José Luis Aranguren (ed.): Obras Completas, Vol. 1. Madrid: Trotta, 1994.

Martikainen, Tuomas: Multilevel and Pluricentric Network Governance of Religion, in: François Gauthier, Tuomas Martikainen (eds.):Religion in the Neoliberal Age.Political Economy and Modes of Governance. New York, NY: Routledge, 2016, pp. 141-154.

Astor, Avi/Griera, Mar/Cornejo, Mónica: Religious Governance in the Spanish City: Hands-on versus Hands-off Approaches to Accommodating Religious Diversity in Barcelona and Madrid, in: Religion, State \& Society 47 (4-5/2019), pp. 390-404.

Astor, Avi: Religious Governance and the Accommodation of Islam in Contemporary Spain, in:Journal of Ethnic and Migration Studies 40 (11/2014), pp. 1716-1735.

Astor, Avi: Governing Religious Diversity amid National Redefinition: Muslim Incorporation in Spain, in: Marian Burchardt/Ines Michalowski (eds.): After Integration: Islam, Conviviality and Contentious Politics in Europe. Wiesbaden: Springer vs, 2015. pp. 247-265.

Audir.org: Xarxa Catalana d'Entitats, https://audir.org/xarxa-catalana-dentitats-2/ (date of last access: April 2020).

Barómetro del cIs. January 2020, http://www.cis.es/cis/export/sites/default/Archivos/ Marginales/326o_3279/3271/es3271mar.html (date of last access: 05.03.2020).

Bramon, Dolors: ¿También Civilización Islamo-Cristiana? ¿y por qué no?, in:Intus-Leger Historia 3 (1/2009), pp. 21-31.

Burchardt, Marian: Recalling Modernity: How Nationalist Memories Shape Religious Diversity in Quebec and Catalonia, in: Nations and Nationalism 23 (3/2017), pp. 599-619.

Burchianti, Flora/Itçaina, Xabier: Local Authorities and Interfaith Dialogue in Spain, in: Council of Europe (ed.): Gods in the City. Intercultural and Inter-religious Dialogue at Local Level. Strasbourg: Council of Europe, 2007, pp. 99-126. 
Cantón Delgado, Manuela: Gitanos Pentecostales: Una Mirada Antropológica a la Iglesia Filadelfia en Andalucía. Andalucía: Signatura Ediciones, 2004.

Casa De Su Majestad El Rey. Actividades e Agenda. Palabras de Su Majestad el Rey en el Acto Institucional Al-Andalus, 04.11.1992, https://www.casareal.es/GL/actividades/ Paginas/actividades_discursos_detalle.aspx $?$ ata $=4650$ (date of last access: 05.05.2020).

Casañas, Joan: El Progressisme Catòlic a Catalunya (1940-1980). Barcelona: La Llar del Llibre, 1988.

Cornejo Valle, Mónica/Pichardo Galán, José Ignacio: Actores y Estrategias en la Movilización anti-Género en España: el Desplazamiento de una Política de Iglesia al Activismo Laico, in: Revista Psicologia Política 18, no. 43 (2018), pp. 524-542.

Delgado, Manuel: La Ira Sagrada. Barcelona: RBA Editores, 2012.

Díez de Velasco, Francisco: The Visibilization of Religious Minorities in Spain, in: Social Compass 57 (2/2010), pp. 235-252.

Díez de Velasco, Francisco: Budismo en España: Historia, Visibilización e Implantación. Madrid: Ediciones Akal, 2013.

Diócesis Málaga. Ecumenismo y Diálogo Interreligioso, https://www.diocesismalaga. es/ecumenismo/ (date of last access: 13.03.2020).

Estruch, Joan: Los Protestantes Españoles. Barcelona: Editorial Nova Terra, 1968.

Estruch, Joan: Secularització i Pluralisme en la Societat Catalana d'avui. Barcelona: Institut d'Estudis Catalans, 1996.

Fundación Pluralismo y Convivencia, La Fundación, https://www.pluralismoyconvi vencia.es/fundacion/ (date of last access: 25.04.2020).

García Hernando, Julián: Colaboración Ecuménica en España en los últimos Veinticinco Años, in: Diálogo Ecuménico 25 (1990), 82-32, pp. 311-339.

Griera, Mar: Public Policies, Interfaith Associations and Religious Minorities: a new Policy Paradigm? Evidence from the Case of Barcelona, in: Social Compass 59 (4/2012), pp. 570-587.

Griera, Mar/Clot-Garrell, Anna: Banal is not Trivial: Visibility, Recognition, and Inequalities between Religious Groups in Prison, in: Journal of Contemporary Religion 30 (1/2015), pp. 23-37.

Griera, Mar: The Governance of Religious Diversity in Stateless Nations: the Case of Catalonia, in: Religion, State \& Society 44 (1/2016), pp. 13-31.

Griera, Mar/Forteza, Maria: New Actors on the Governance of Religious Diversity in European cities: The Role of Interfaith Platforms, in: Jeff Hayes/Anja Hennig (eds.): Religious Actors in the Public Sphere: Means, Objectives and Effects. New York, NY: Routledge, 2011, pp. 113-131.

Griera, Mar/Burchardt, Marian/Astor, Avi: European Identities, Heritage, and the Iconic Power of Multi-Religious Buildings: Cordoba's Mosque Cathedral and Berlin's House of One, in: Giuseppe Giordan/Andrew P. Lynch: Interreligious Dialogue: From Religion to Geopolitics. Leiden: Brill, 2019, pp. 13-31. 
Martikainen, Tuomas: Multilevel and Pluricentric Network Governance of Religion, in: François Gauthier/Tuomas Martikainen (eds.): Religion in the Neoliberal Age. Farnham: Ashgate, 2013, pp. 129-142.

Griera, Mar/Nagel, Alexander-Kenneth: Interreligious Relations and Governance of Religion in Europe: Introduction, in: Social Compass 65, (3/2018), pp. 301-311.

Halafoff, Anna: The Multifaith Movement: Global Risks and Cosmopolitan Solutions. Dordrecht: Springer, 2013.

Heelas, Paul/Woodhead, Linda/Seel, Benjamin/Szerszynski, Bronislaw/Tusting, Karin: The Spiritual Revolution: Why Religion is Giving Way to Spirituality. Oxford: Blackwell, 2005 .

Itçaina, Xabier: The Roman Catholic Church and the Immigration Issue: the Relative Secularization of Political Life in Spain, in: American Behavioral Scientist 49 (11/2006), pp. 1471-1488.

Lamine, Anne-Sophie: La Cohabitation des Dieux. Pluralité Religieuse et Laïcité. Paris: Presses universitaires de France, 2004.

Lehmann, Karsten (ed.): Interreligious Dialogue in Context: Towards a Systematic Comparison of IRD-Activities in Europe, JRAT $6\left(2 / 202 \mathrm{O}^{2}\right)$.

Martikainen, Tuomas: Multilevel and Pluricentric Network Governance of Religion, in: François Gauthier/Tuomas Martikainen (eds.): Religion in the Neoliberal Age. Farnham: Ashgate, 2013, pp. 129-142.

Martínez-Ariño,Julia/Griera, Mar/García-Romeral, Gloria/Forteza, Maria:Inmigración, Diversidad Religiosa y Centros de Culto en la Ciudad de Barcelona, in: Migraciones. Publicación del Instituto Universitario de Estudios sobre Migraciones, no. 30 (2011), pp. 101-133.

Montañes, Antonio: Etnicidad e Identidad Gitana en los Cultos Pentecostales de la Ciudad de Madrid. El Caso de la Iglesia Evangélica de Filadelfia y el Centro Cristiano Vino Nuevo el Rey Jesús, in: Papeles del CEIC. International Journal on Collective Identity Research (2/2016), pp. 1-26.

Moreras Palenzuela, Jordi: ¿Ravalistán? Islam y Configuración Comunitaria entre los Paquistaníes en Barcelona, in: Revista CIDOB d'Afers Internacionals, no. 68 (2004), pp. 119-132.

Motilla, Agustín: El Islam en España: Marco Legal, in: Angels Roque (ed.): El islam plural. Barcelona: Icaria, 2003, pp. 313-334.

Observatorio Religion. Observatorio del Pluralism Religioso en España, http://www. observatorioreligion.es/upload/71/73/ExplotacionDic2018.pdf (date of last access: 05.03.2020).

Pérez-Agote, Alfonso. Religion, Politics and Culture in Spain: Towards a Historical Sociology of their Differentiation and their Relations, in: Politics and Religion Journal 9 (2/2015), pp. 213-232. 
Perini, Pietro de: The Changing Scope of Intercultural Dialogue in EU Mediterranean Policy, in: Mediterranean Politics 4 (2019), DoI: 10.1080/13629395.2019.1605757.

Rozenberg, Danielle: Minorías Religiosas y Construcción Democrática en España (Del Monopolio de la Iglesia a la Gestión del Pluralismo), in: Reis, no. 74 (1996), pp. $245^{-265}$.

Ruiz Poveda, Luís: El Ecumenismo y los Ecumenismos en España. Anales de Historia Contemporánea, Vol. 17. 2001, pp. 377-383.

Salguero Montaño, Óscar: Estrategias de Institucionalización del Islam en Contextos Migratorios: el Caso de Baitul Muqarram, in:International Journal of Organizations/ Revista Internacional de Organizaciones, no. 22 (2019), pp. 55-79.

Seglers, Alex: Autogovern i fet Religiós: Una Gestió del Pluralisme Religiós a Catalunya. Barcelona: Proa, 2000.

Taylor, Charles: A Secular Age. Cambridge: Harvard University Press, 2007.

Torradeflot, Francesc: Las Vías del Diálogo Interreligioso en España. Documentos del Observatorio No. 3, http://www.observatorioreligion.es/upload/53/94/Religiones_ y_Pluralismo._Las_vias_del_dialogo_interreligioso_en_Espana.pdf (date of last Access: 03.09 .2020 ). 